\title{
Fortification of pizza dough's with whole soybean flour of new cultivar 'UFVTN 105AP'
}

\author{
Fortificação de massas de pizza com farinha integral de soja do novo cultivar 'UFVTN 105AP'
}

\author{
Dorina Isabel Gomes Natal ${ }^{\mathrm{I}}$ Maria Inês de Souza Dantas ${ }^{\mathrm{I}}$ \\ Márcia Cristina Teixeira Ribeiro Vidigal ${ }^{\mathrm{II}}$ Sônia Machado Rocha Ribeiro ${ }^{\mathrm{I}}$ \\ Newton Deniz Piovesan ${ }^{\mathrm{III}}$ Hércia Stampini Duarte Martino ${ }^{\mathrm{I}^{*}}$ Desirrê Morais Dias $^{\mathrm{I}}$
}

\begin{abstract}
This study aimed to characterize the physicochemical properties and the correlation between the instrumental texture and the sensory acceptance of pizza dough's fortified with whole soybean flour. Formulations were developed to contain $0 \%$, $30 \%, 50 \%$ and $70 \%$ whole soybean flour. The texture analysis indicated that the addition of 50\% soybean increased $(P<0.05)$ firmness, gumminess, springiness and chewiness of pizza dough. The contents of protein, dietary fiber and and minerals calcium zinc, magnesium, potassium, copper and phosphorus were higher $(P<0.05)$ with increasing concentration of soybean flour. The content of lipid was higher $(P<0.05)$ in the pizza dough with $70 \%$ whole soybean flour. The control formulation and that containing $30 \%$ whole soybean flour were the most accepted, being positively correlated with the instrumental texture, since it had a lower firmness, gumminess, springiness and chewiness. Thus, the whole soybean flour added antioxidant minerals, protein, dietary fiber, essential fatty acids ( $\omega-6$ and $\omega-3)$ and maintained the acceptance of the pizza dough's, allowing to prepare food with health claim and sensory quality.
\end{abstract}

Key words: Functional ingredients, chemical composition, sensory acceptability.

\section{RESUMO}

Objetivou-se caracterizar as propriedades físicoquímicas e a correlação entre a textura instrumental e a aceitação sensorial de massas de pizza fortificadas com farinha integral de soja. Foram desenvolvidas formulações contendo 0\%, 30\%, 50\% e $70 \%$ de farinha integral de soja. A análise de textura indicou que a adição de $50 \%$ de soja elevou $(P<0,05)$ a dureza, gomosidade, elasticidade e mastigabilidade da massa de pizza. Os teores de proteina, fibra alimentar e dos minerais cálcio, zinco, magnésio, potássio, cobre e fósforo foram maiores $(P<0,05)$ com o aumento da concentração da farinha de soja. O conteúdo de lipídio foi maior
$(P<0,05)$ na massa de pizza com $70 \%$ de farinha integral de soja. A formulação controle e aquela contendo $30 \%$ de farinha integral de soja foram as mais aceitas, sendo positivamente correlacionadas com a textura instrumental, uma vez que apresentaram menor dureza, gomosidade, elasticidade e mastigabilidade. Portanto, a farinha de soja adicionou minerais antioxidantes, proteína, fibra dietética, ácidos graxos essenciais ( $\omega$ - 6 e $\omega$-3) e manteve a aceitação das massas de pizza, possibilitando o preparo de um alimento com alegação de saúde e qualidade sensorial.

Palavras-chave: ingredientes funcionais, composição química, aceitabilidade sensorial.

\section{INTRODUCTION}

The development of new products is an area of research gaining increasing prominence in the light of growing consumer demands for foods with high nutritional value and functional characteristics. The soybean is a food that arises in this context, being used in several studies of new food formulations (SCHMIELE et al., 2011; NATAL et al., 2013) due to its high nutritional value and functional properties, which contain flavonoids, fiber and bioactive peptides. However, soybean contains lipoxygenases, related to lipid peroxidation, which causes the beany flavor and thus restricts the consumption of legumes. To overcome this problem and increase the consumption of soybeans, lipoxygenases-free cultivars with improved flavor are being developed (ESTEVES et al., 2011).

\footnotetext{
'Departamento de Nutrição e Saúde, Universidade Federal de Viçosa (UFV), Campus Universitário S/N, 36570-000, Viçosa, MG, Brasil. E-mail: hercia@ufv.br.*Autor para correspondência.

"Departamento de Tecnologia de Alimentos, UFV, Viçosa, MG, Brasil.

IIIDepartamento de Biologia Geral, Instituto de Biotecnologia Aplicada à Agropecuária (BIOAGRO), UFV, Viçosa, MG, Brasil.
} Received 05.16.13 Approved 03.04.14 Returned by the author 06.14.14
CR-2013-0687.R1 
Pizza is distinguished as a traditional bakery product in European countries, with growing popularity in American countries, such as the United States and Brazil, primarily as snack (BEZERRA et al., 2013; FORD et al., 2013). Just as with traditional bread, pizza has very pleasant aroma and flavor, is easily prepared and is of relatively low cost, which certainly contributes to its increased consumption. Despite its popularity, pizza dough's present low nutrients densities and bioactive compounds since they are prepared from refined wheat flour (SCHMIELE et al., 2011).

The increase of functional ingredients is a good alternative to produce health foods, but the modification of the sensory characteristics should be considered to ensure the consumption these products. Know to that the reduction of wheat flour and the addition of flours with high content of the fiber dietary and absence gluten decreases the capacity incorporation of air in the dough, increasing the texture of the same (GOMÉZ, et al., 2010). Moreover, the addition of soy or other integral food change the color, the flavor and the appearance of products, reducing, consequently, its acceptance (SCHMIELE et al., 2011).

Studies have been used low percentage of soybean flour to replace wheat flour at bakery products (WANG et al., 2005; SCHMIELE et al., 2011). It is necessary investigate the effects of replace high amount of wheat flour by soybean flour at bakery product. Therefore, the aim of this work was to characterize the physicochemical properties and the correlation between the instrumental texture and the sensory acceptance of pizza dough's fortified with whole soybean flour.

\section{MATERIALS AND METHODS}

For the preparation of soybean flour was used the cultivar 'UFVTN 105AP', developed by the Soybean Breeding Program of the Biotechnology Institute of the Universidade Federal de Viçosa (BIOAGRO/ UFV). The cultivar developed without the three isoforms of enzymes lipoxygenases, has high protein content from the 2009 harvest (MARTINO et al., 2011).

Preparation of whole soybean flour

Soybeans were selected, washed, dried at room temperature and subjected to heat treatment at $150^{\circ} \mathrm{C}$ for 30 minutes in an oven with air circulation. The grains were grounded in a rotor mill with 30 mesh sieve. The resulting flour was stored in polyethylene bags at $-22^{\circ} \mathrm{C}$ for later use in the development of pizza dough's.

Development of pizza dough's

Four pizza dough formulations were developed, being the control formulation and addition of $30 \%, 50 \%$ and $70 \%$ whole soybean flour in partial replacement of refined wheat flour. The amount of soybean oil added varied depending on the lipid concentration in the soybean flour (MARTINO et al., 2011). The water added to pizza was to allow for proper rolling of the dough. The other ingredients, yeast and refined salt, were added with similar concentration.

Yeast was diluted in water at $30^{\circ} \mathrm{C}$. Salt and oil were then added, homogenizing the dough by hand. Wheat and soybean flours were added gradually until the dough was thin and elastic. Then the mass was covered with a polyethylene film and left at room temperature for 30 minutes to stimulate the fermentation process. Afterwards the dough was rolled with a manual roller to obtain the approximate thickness of $4 \mathrm{~mm}$, and cut into circular shape with a diameter of $4.6 \mathrm{~cm}$. The pizza dough's were prebaked pizza in a conventional oven gas at $280^{\circ} \mathrm{C}$ for 15 minutes. The relation between pre-baked and raw pizzas was used to quantify the proceeds.

Pizza dough's pre-baked were prepared in a single lot for analysis. The sensory analyze were in complete randomize block design with 100 judges and texture profile and chemical analysis in three repetitions and three replicate for each sample. All the formulations were stored in polyethylene bags at $-22^{\circ} \mathrm{C}$.

\section{Texture Profile Analysis (TPA)}

The pizza dough formulations were subjected to TPA compression in the Universal Testing Machine Mechanical. The samples were stored at $-22^{\circ} \mathrm{C}$ for one week, thawed and placed in an oven for 5 minutes at $280^{\circ} \mathrm{C}$ in the day of analysis. A $50 \mathrm{~mm}$ diameter probe was moved perpendicularly over the a disc shaped pizza dough samples with a diameter of $50 \mathrm{~mm}$ and height $5 \mathrm{~mm}$. A crosshead speed of $1.5 \mathrm{~mm} \mathrm{~s}^{-1}$ was used to compress the central area of pizza base samples to $40 \%$ of their original height. Samples were placed centrally beneath the probe in order that the probe met with a consistently flat surface at all times. Each sample was compressed twice in a reciprocating motion to give a two-bite texture profile curve.

The force exerted on the samples was automatically recorded and the firmness, chewiness,

Ciência Rural, v.44, n.9, set, 2014. 
gumminess, cohesiveness and springiness were calculated automatically from the force $(\mathrm{N}) \times$ time (s) curves generated during the test by the Blue Hill software 2.0.

\section{Chemical analysis}

Moisture, protein, lipid, ash and dietary fibers analyses were performed according to AOAC (2005) and carbohydrate content was calculated as the difference. The caloric value was calculated by summing the calories supplied by proteins, carbohydrates and lipids, using the conversion factors $4 \mathrm{kcal} \mathrm{g}^{-1}, 4 \mathrm{Kcal} \mathrm{g}^{-1}$ and $9 \mathrm{kcal} \mathrm{g}^{-1}$, respectively. Analysis of minerals was performed according GOMES et al., (2003) and fatty acids were quantified by gas chromatography (FOLCH et al., 1957; HARTMANN \& LAGO, 1973).

\section{Sensory analysis}

Acceptance of pizza dough's was tested in a supermarket in the city of Viçosa, MG, Brazil. Acceptability tests were previously approved by the ethics committee of the Federal University of Viçosa, protocol number 101/2009.

Pre-baked pizza dough's, weighing approximately $5 \mathrm{~g}$, were prepared and stored at $-22^{\circ} \mathrm{C}$ one day before the sensory test. These pizzas were covered with $3 \mathrm{~g}$ of mozzarella cheese and placed in an oven for 5 minutes at $280^{\circ} \mathrm{C}$ in the day of the analysis. The samples were identified with three digit codes and presented to consumers individually, according to the randomized block design. Participated in this study 43 men and 57 women aged between 15 and 70 years old.

Consumers rated the overall acceptability of the formulations using a nine point's hedonic scale (REIS et al., 2006) and responded to the intention of purchasing the products.

\section{Statistical analysis}

The instrumental texture parameters were submitted using the techniques of Analysis of Variance (ANOVA) and the Principal Component Analysis (PCA). Sensory characteristics were assessed to ANOVA and also by the Internal Preference Mapping methodology. The chemical analysis were evaluated by ANOVA following to the post hoc test, Tukey at $5 \%$ probability, with the exception of dietary fiber, fatty acids and carbohydrates.

Analyses of the correlations (Pearson) were performed between the instrumental texture parameters and the principal components obtained from PCA of sensorial acceptability data. All statistical analyzes were performed using Statistical Analysis System (SAS), version 9.1 (2009), licensed for use by the Federal University of Viçosa.

\section{RESULTS AND DISCUSSION}

Pizza dough's with whole soybean flour presented higher proceeds $(0.80,0.82$ and 0.84$)$ for the pizzas with $30 \%, 50 \%$ and $70 \%$ of whole soybean flour than the control (0.78).

Texture Profile Analysis (TPA)

The addition of soybean flour altered $(\mathrm{P}<0.05)$ the firmness, gumminess, chewiness and elasticity of pizza dough's. Cohesiveness was not affected $(\mathrm{P}>0.05)$ in different soybean flour concentrations. We expected change of the texture of pizza dough's, since the soybean flours has low starch content than wheat flour and absence of the gluten protein (EL-DASH et al., 1994; KARRLILIENTHAL et al., 2005).

The average values of the instrumental texture parameters were submitted to the Principal Component Analysis (PCA) (Figure 1). The first principal component explained $99.63 \%$ of the total data variation, being sufficient to discriminate the samples. The spatial arrangement of the samples in relation to the first principal component suggests the formation of two distinct groups. One group formed by the control formulation and that to which $30 \%$ soybean, and another by the formulations with $50 \%$ and $70 \%$. The firmness, springiness, gumminess and chewiness were positively correlated with only the first principal component, showing that formulations containing $50 \%$ and $70 \%$ soybean flour, located to the right of figure 1, showed the highest instrumental texture parameters.

The addition of $30 \%$ soybean flour to the pizza dough did not affect firmness, springiness, gumminess and chewiness, but texture of the formulation with $50 \%$ was modified. Thus, the reduction of $50 \%$ of wheat flour in the formulations affected negatively the texture characteristics of the pizza dough's (Figure 1).

\section{Chemical analysis}

Increasing the amount of soybean flour in the formulations caused a rise in the protein content $(\mathrm{P}<0.05)$ (Table 1). This trend was also observed in the levels of soluble, insoluble and total dietary fiber. Moisture did not differ $(\mathrm{P}>0.05)$, although the content 


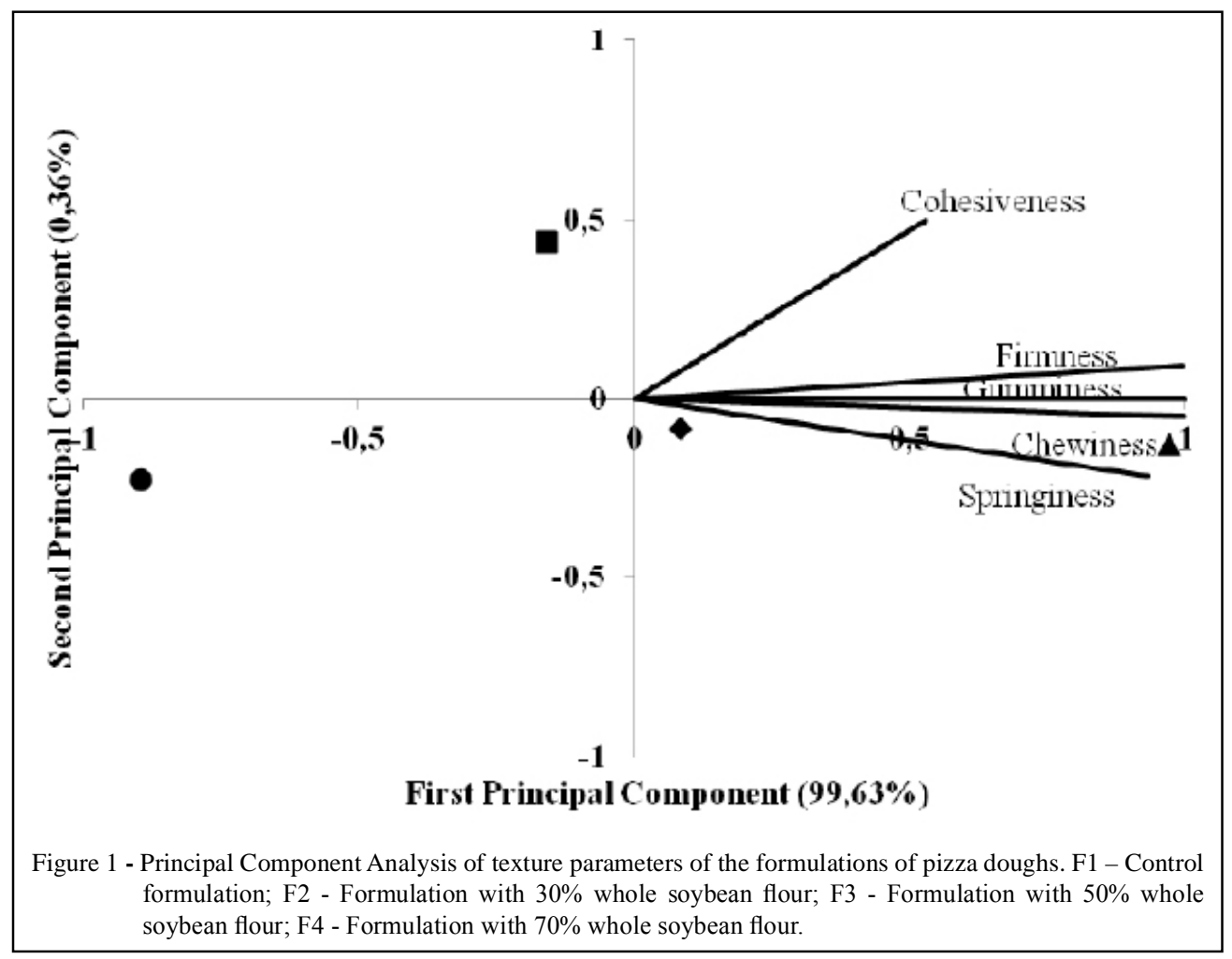

of water added to pizzas have been reduced. The yield of dough's with soybean flour was lower in relation to control, due the reduction of the gluten protein and of the fermentation (KARR-LILIENTHAL et al., 2005). So, the humidity of the four formulations was proportionally the same. The lipid concentrations differed $(\mathrm{P}<0.05)$ between the control and the formulation with the highest concentration of soybean. The decrease soy oil for each formulation was estimate accord with MARTINO et al., (2011). However, when the formulations were analyzed deference was observed. Carbohydrates were reduced $22 \%$ in each preparations, since that the soybean flour presented a level lower of carbohydrate in relation to wheat flour. This reduction contributed to a $3.3 \%$ decrease of the caloric value of each formulation.

PHILIPPI (2008) classify food as nutrient source from 5 to $10 \%$ of the Dietary Reference Intake (DRI), as good source from 10 to $20 \%$ of the DRI and as excellent source more of $20 \%$ of the DRI (IOM, 2006). Considering the average of DRI for adult women and men, with aged between 19 and 50 years and the portion of $50 \mathrm{~g}$ indicated by legislation, all pizza dough formulations with whole soybean flour were considered good sources of protein. According to BRASIL (2008), daily consumption of at least $25 \mathrm{~g}$ of soybean protein can aid to lower cholesterol, since its consumption is associated with a balanced diet and healthy lifestyle. It is noteworthy that the soybean used in the preparation of the pizza dough's presented a amino acid balance better that the conventional, not being deficient in methionine, cysteine and tryptophan (CARVALHO et al., 2013). Therefore, the protein the whole soybean flour of cultivar 'UFVTN 105AP' is more nutritionally adequate in relation to conventional and can provides greater benefit to health of consumers these pizzas fortified.

Formulations with $30 \%$ and $50 \%$ soybean flour were classified as good sources of dietary fiber and the formulation with $70 \%$, as excellent source. Therefore, the pizza dough's can be classified as whole grain products and provide health claims, since they can assist in bowel function (BRASIL, 2008).

The levels of calcium, zinc, magnesium, potassium, copper and phosphorus increased in the formulations fortified with soy (Table 1), while the levels of iron and sodium were unaltered $(\mathrm{P}>0.05)$. The increased mineral content in formulations occurred due to the high level of these micronutrients in soybean (MARTINO et al., 2011). The formulations added soybean flour were considered good sources of zinc, copper and phosphorus, and excellent sources of iron and manganese. Formulations with $30 \%$ and $50 \%$ soybean flour were classified as sources 
Table 1 - Chemical composition proximate $\left(\mathrm{g} \cdot 100 \mathrm{~g}^{-1}\right)$, caloric value $(\mathrm{Kcal})$, minerals $\left(\mathrm{mg} \cdot 100 \mathrm{~g}^{-1}\right)$, fatty acid composition $\left(\mathrm{g} \cdot 100 \mathrm{~g}^{-1}\right)$ and $\omega-6 /$ $\omega-3$ ratio of pizza dough's.

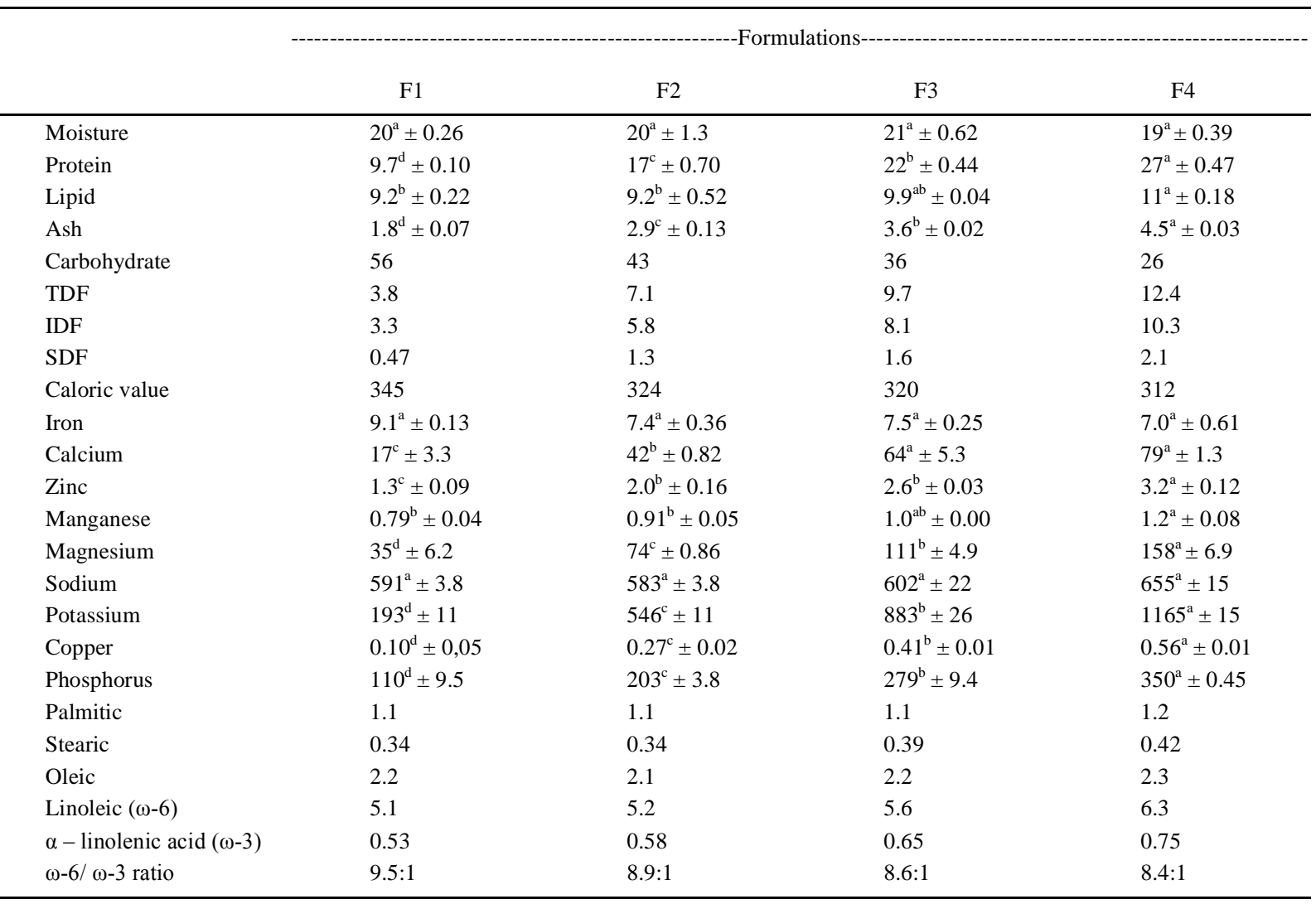

Means followed by same letter in the same row do not differ by Tukey test, a $5 \%$ probability.

F1 - Control formulation; F2 - Formulation with $30 \%$ whole soybean flour; F3 - Formulation with $50 \%$ whole soybean flour; F4 Formulation with $70 \%$ whole soybean flour.

TDF - Total Dietary Fiber; IDF - Insoluble Dietary Fiber; SDF - Soluble Dietary Fiber.

of potassium and good source of magnesium, while the formulation with $70 \%$ was a good source of potassium and excellent source of magnesium. With regards to sodium, although all formulations are considered good sources, the concentration of the mineral did not exceed $16.4 \%$ of DRI. Considering that fast foods have high concentrations of sodium and that controlling the intake of this mineral is important in reducing risks of cardiovascular disease, pizza dough's are a good alternative.

The pizza dough's with soybean presented higher concentrations of minerals antioxidant, such zinc, magnesium and copper, which makes them foods which aid in protecting against noncommunicable diseases. The calcium content of the formulations were higher as the concentration of soybean was increased, making the products an alternative to complement the adequate intake of calcium and prevent osteoporosis (REINWALD \& WEAVER, 2010).

The four pizza dough's were excellent sources of $\omega-6$ and $\omega-3$. Therefore, the developed pizza dough's can contribute to a balanced diet, providing a strategy to address the high $\omega-6 / \omega-3$ ratio characteristic of the Western diet. Table 1.

Sensory analysis

Consumers in general preferred the formulations control and with $30 \%$ soybean, which presented a higher number of scores 6-9. However, all the formulations were good accepted, probably in function of use of soybean without lipoxygenases. There were significant differences among consumers, by ANOVA, with mean score values of 7.2, 7.1, 6.6 and 6.0, respectively, to formulations with $0 \%, 30 \%$, $50 \%$ and $70 \%$ of soybean. 
However, the scores of the four formulations showed high variation, meaning that there was a high note variation of liking responses for the same formulation. For this reason, Internal Preference Mapping was conducted to determine whether distinct segments of consumers could be detected.

Internal Preference Mapping of all consumer showed that about $82 \%$ of the variation was explained by two first principal components, sufficient to discriminate difference among formulations. The spatial arrangement of the samples suggest the formation of three distinct groups: a group represented by the control and formulation with $30 \%$ of soybean and two groups representing the formulations with $50 \%$ and $70 \%$. Each point represents the correlations between acceptance data from a consumer and the first two principal components. Consumers closest to the center of the chart are not correlated with either of the two principal components and contribute little to discrimination of the samples. The largest number of consumers positively correlated with first principal component indicated greater acceptance of control samples and 30\% soybean flour (Figure 2)

Most consumers responded positively in terms of intention to purchase the control and formulations with $30 \%$ and $50 \%$ soybean flour, representing about $70 \%$. Despite the lower acceptance, about $50 \%$ of consumers said they would purchase the pizza dough with $70 \%$.

Correlation of instrumental texture parameters with the sensory acceptability

The instrumental texture characteristics responsible for the difference in acceptability of the pizza dough's were identified by the correlation analysis between texture parameters and the first two principal components obtained from the PCA of acceptance data (Figure 3).

The first two principal components explained $86.6 \%$ of the data variation, being sufficient to explain the data. The instrumental texture parameters, except for cohesiveness, were negatively correlated $(\mathrm{P}<0.10)$ with the first principal component, and consumer presented the opposite behavior, focusing on the positive region of the $\mathrm{x}$ axis.

The correlation analysis between texture attributes and acceptability indicated that greater firmness, chewiness, gumminess and springiness of pizza dough's negatively affected their acceptability. Therefore, the instrumental texture parameters are important tools to aid in development of products with good acceptability. Figure 3 .

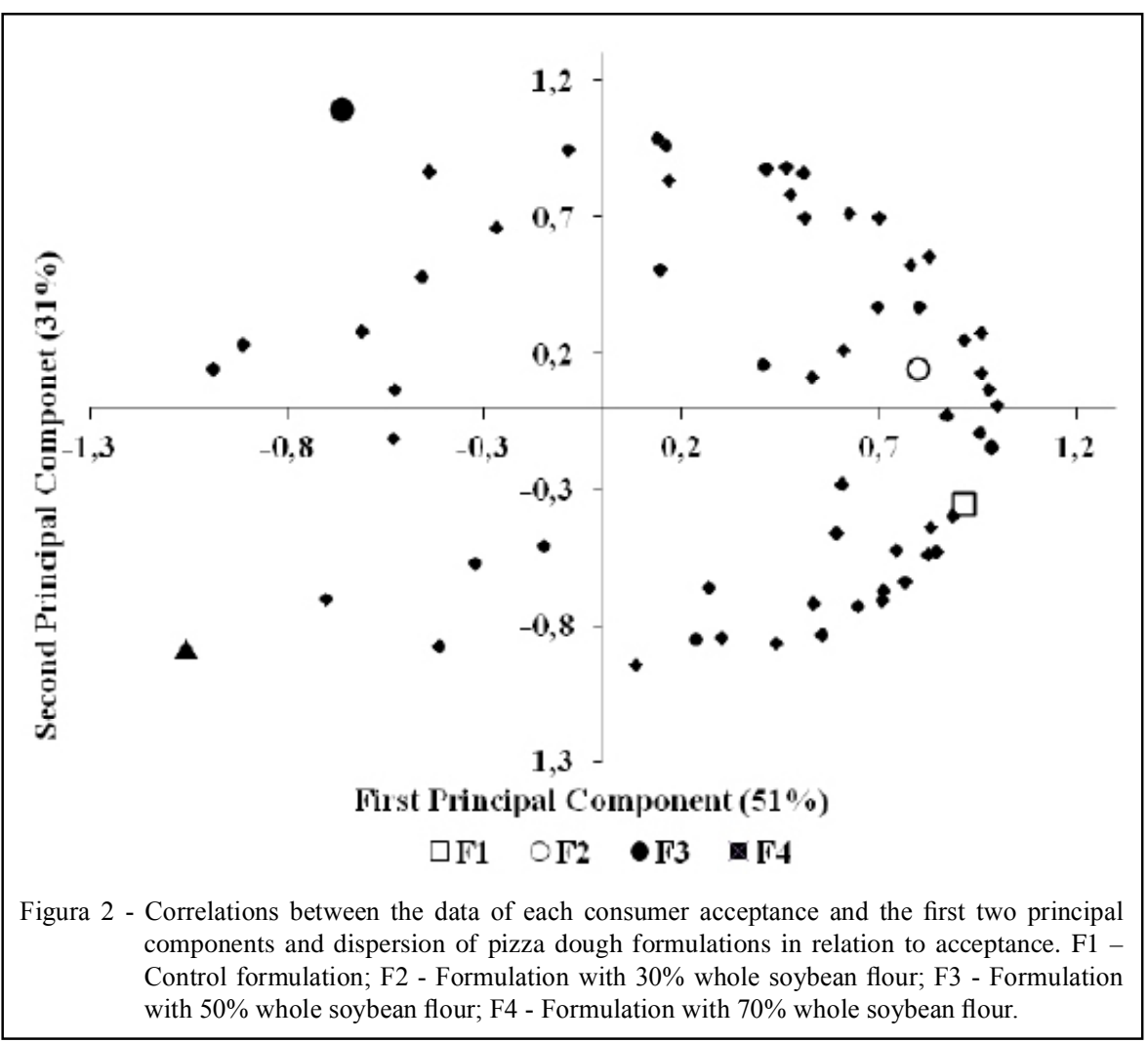

Ciência Rural, v.44, n.9, set, 2014. 


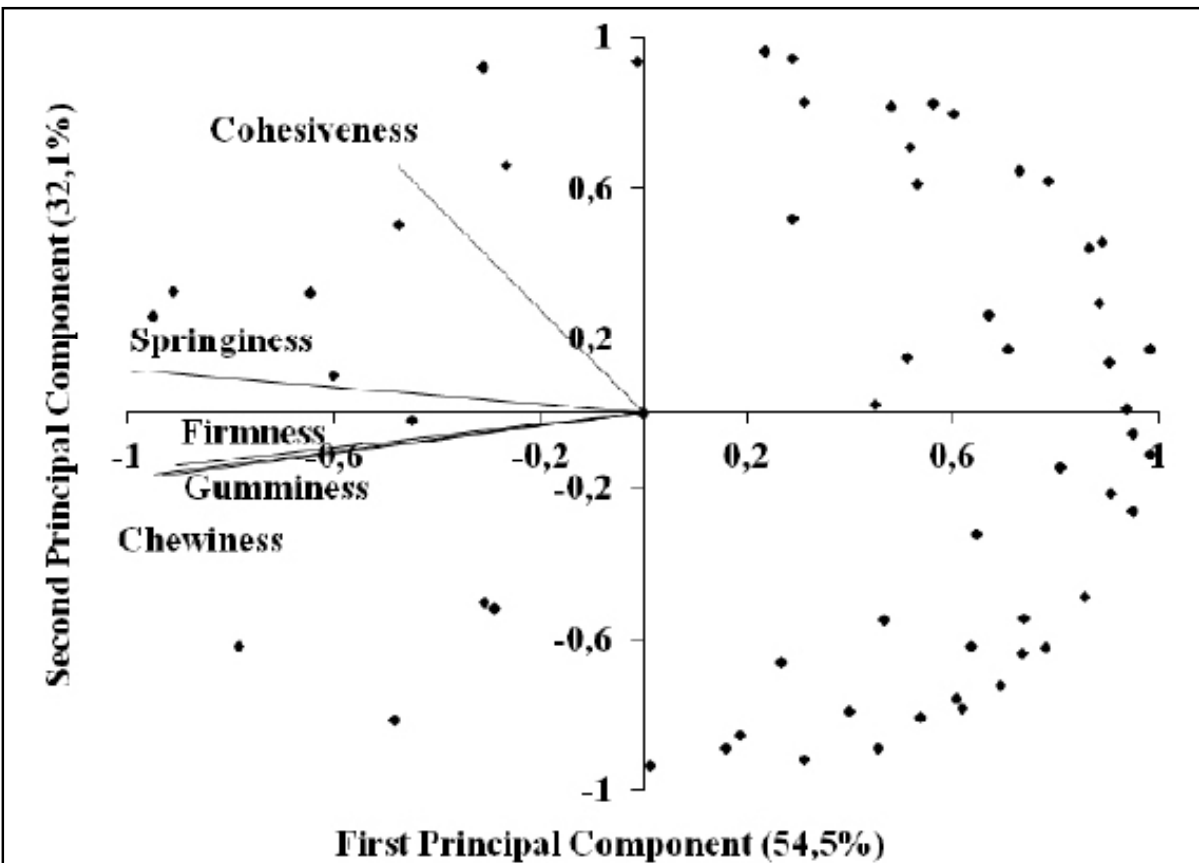

Figure 3 - Correlation of instrumental texture parameters and consumer with the principal components.

\section{CONCLUSION}

The addition of soybean flour in the development of pizza dough's adds added antioxidant minerals (zinc, magnesium and copper), protein, fiber dietary and essential fatty acids ( $\omega-6$ and $\omega-3)$, and also allowed that health claim be made for the products. Acceptance of pizza dough's was influenced by texture, since the formulation with lower firmness, gumminess, chewiness and elasticity was the most acceptable.

Thus, best formulation in relation to the physicochemical and sensory characteristics was the pizza dough with $30 \%$ soybean, indicating that the replacement of refined wheat flour is a viable option for development of foods with health claims and sensory quality.

\section{ACKNOWLEDGEMENTS}

Fomentation of this study by Fundação de Amparo à Pesquisa do estado de Minas Gerais (FAPEMIG); Programa Institucional de Bolsas de Iniciação Científica (PIBIC), Conselho Nacional de Desenvolvimento Científico e Tecnológico (CNPq).

\section{REFERENCES}

AOAC (ASSOCIATION OF OFFICIAL ANALYTICAL CHEMISTS). Official Methods of Analysis. 18.ed. Gaithersburg, Maryland, 2005. 25p.
BRASIL. Alimentos com Alegações de Propriedades Funcionais e ou de Saúde, Novos Alimentos/Ingredientes, Substâncias Bioativas e Probióticos. Diário Oficial da República Federativa do Brasil, atualizado em julho de 2008. Available from: <http://www.anvisa. gov.br/alimentos/comissoes/tecno_lista_alega.htm>. Accessed: jan 10, 2013.

CARVALHO, A.W. et al. Heat-treatment reduces antinutritional phytochemicals and maintains protein quality in genetically improved hulled soybean flour. Ciência e Tecnologia de Alimentos, v.33, n.2, 2013. Available from: <htpp//www.dx.doi.org.10.1590/S010120612013005000048>. Accessed: jul 05, 2013. doi: 10.1590/ S0101-20612013005000048.

ESTEVES, E.A. et al. Chemical composition of a soybean cultivar lacking lipoxygenases (LOX2 and LOX3). Food Chemistry, v.122, p.238-242, 2010. Available from: <http://www.dx.doi. org.10.1016/j.foodchem.2010.02.069>. Acessed: jul 10, 2011. doi: 10.1016/j.foodchem.2010.02.069.

FOLCH, L. et al. A simple method for the isolation and purification of total lipids from animal tissues. Journal of Biological Chemistry, v.226, p.497-509, 1957. Available from: <http://www. jbc.org/content/226/1/497.long>. Accessed: oct 08, 2010.

GOMES, J.C. et al. Análise de alimentos. 2.ed. rev e at. Viçosa: FUNARBE, 2003. 153p

HARTMANN, L.; LAGO, B.C.A. Rapid preparation of fatty acid methyl esters from lipids. Laboratory Practices, v.22, p.475-477, 1973. Available from: <htpp//www.dx.doi.org. 10.1021/ac60235a044>. Accessed: nov 15, 2011. doi: 10.1021/ ac60235a044. 
IOM (INSTITUTE OF MEDICINE). The dietary reference intakes: the essencial guide to nutrient requeriments. Washington, DC: National Academies, 2006. 1344p.

KARR-LILIENTHAL, L.K. et al. Chemical and nutritional properties of soybean carbohydrates as related to nonruminants: a review. Livestock Production Science, v.97, p.1-12, 2005. Available from: 〈htpp://www.dx.doi.org.10.1016/j.livprodsci.2005.01.015>. Accessed: 02 may, 2011. doi: 10.1016/j.livprodsci.2005.01.015.

MARTINO, H.S.D. et al. Heat-treated hull flour does not affect iron bioavailability in rats. Archivos Latinoamericanos de Nutrición, v.61, n.2, p.135-142, 2011. Available from: <http://www.alanrevista. org/ediciones/2011-2/pdf/art4.pdf >. Accessed: jan 19, 2012

NATAL, D.I.G. et al. Physical and sensorial properties of potato breads fortified with whole soybean flour. Revista Chilena de Nutrición, v.40, n.1, p.62-70, 2013. Available from: <htpp://www. dx.doi.org.10.4067/S0717-75182013000100010>. Accessed: apr 10, 2013. doi: 10.4067/S0717-75182013000100010.
PHILIPPI, S.T. Pirâmide dos alimentos - Fundamentos básicos da nutrição. Barueri, SP: Manole, 2008. 378p.

REINWALD, S.; WEAVER, C.M. Soy components vs. whole soy: are we betting our bones on a long shot? Journal of Nutrition, v.140, p. 2312-2317, 2010. Available from: <htpp://www.dx.doi. org.10.3945/jn.110.124008>. Accessed: jul 09, 2012. doi: 10.3945/ jn.110.124008.

REIS, R.C. et al. Mapa de preferência. In: MINIM, VPR Análise sensorial: estudo com consumidores. Viçosa: UFV, 2006. p.13-50

SCHMIELE, M. et al. Influência da adição de farinha integral de aveia, flocos de aveia e isolado proteico de soja na qualidade tecnológica de bolo inglês. Boletim do Centro de Pesquisa de Processamento de Alimentos, v.29, n.1, p.71-82, 2011. Available from: <ojs.c3sl.ufpr.br/ojs/index.php/alimentos/article/ view/22751/16539>. Accessed: jul 13, 2013. 